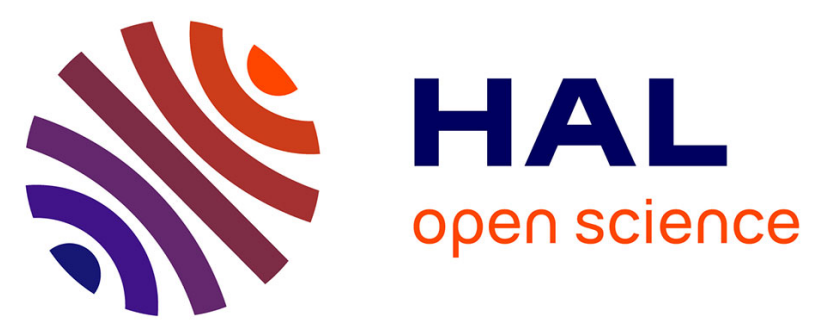

\title{
Elaboration of a new ceramic membrane support from Cameroonian clays, coconut husks and eggshells: application for Escherichia coli bacteria retention
}

P. Kamgang-Syapnjeu, D. Njoya, E. Kamseu, L. Cornette de Saint Cyr, A. Marcano-Zerpa, Sebastien Balme, Mikhael Bechelany, L. Soussan

\section{To cite this version:}

P. Kamgang-Syapnjeu, D. Njoya, E. Kamseu, L. Cornette de Saint Cyr, A. Marcano-Zerpa, et al.. Elaboration of a new ceramic membrane support from Cameroonian clays, coconut husks and eggshells: application for Escherichia coli bacteria retention. Applied Clay Science, 2020, 198, pp.105836. 10.1016/j.clay.2020.105836 . hal-03241190

\section{HAL Id: hal-03241190 \\ https://hal.umontpellier.fr/hal-03241190}

Submitted on 28 May 2021

HAL is a multi-disciplinary open access archive for the deposit and dissemination of scientific research documents, whether they are published or not. The documents may come from teaching and research institutions in France or abroad, or from public or private research centers.
L'archive ouverte pluridisciplinaire HAL, est destinée au dépôt et à la diffusion de documents scientifiques de niveau recherche, publiés ou non, émanant des établissements d'enseignement et de recherche français ou étrangers, des laboratoires publics ou privés. 


\section{Elaboration of a new ceramic membrane support from Cameroonian clays,} coconut husks and eggshells: application for Escherichia coli bacteria retention

\section{P. Kamgang-Syapnjeu ${ }^{1}$, D. Njoya ${ }^{1}$, E. Kamseu ${ }^{2}$, L. Cornette de Saint Cyr ${ }^{3}$, A. Marcano-} Zerpa $^{3}$, S. Balme ${ }^{3}$, M. Bechelany ${ }^{3}$, L. Soussan ${ }^{3 *}$

${ }^{1}$ Laboratory of Applied Inorganic Chemistry, University of Yaounde 1, PO. Box 812 Yaounde, Cameroon. ${ }^{2}$ Laboratory of Materials Analysis, MIPROMALO, PO. Box 2396, Yaounde, Cameroon.

${ }^{3}$ Institut Européen des Membranes, IEM - UMR 5635, ENSCM, CNRS, Univ. Montpellier, Montpellier, France *Corresponding author: Laurence.Soussan@umontpellier.fr

\section{Abstract}

In this work, the feasibility to elaborate a membrane support for water treatment from Cameroonian clays, coconut husks and eggshells was assessed. Twenty-five plastic formulations with different percentage of raw materials were tested and consolidated by thermal treatment to get the membrane supports. Mercury porosimetry allowed to select five supports potentially eligible for water filtration since their porosities were higher than $50 \%$. Mechanical resistance and water absorption

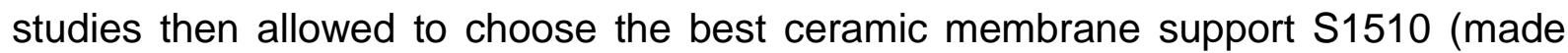
from clays $75 \%$, coconut husks $15 \%$ and eggshells $10 \%$ after sintering at $900^{\circ} \mathrm{C}$ ). EDX, XRD, TGA/DSC, FTIR and SEM characterizations techniques were used to characterize the raw materials and selected membrane support. The selected support has $52 \%$ of porosity, a mean pore diameter of $0.08 \mu \mathrm{m}$ and a water permeability of $14013 \mathrm{~L} / \mathrm{h} / \mathrm{m}^{2} / \mathrm{bar}$. The ability of the support to retain $E$. coli bacteria present in a contaminated water was finally assessed. Retention tests showed $90 \%$ 
of E. coli removal, making this membrane support interesting for microfiltration purpose.

Keywords: Membrane support; Clays; Coconut husks; Eggshells; E. coli retention.

\section{Introduction}

The main microbial risks on health are generally associated with the ingestion of water contaminated by human or animal (including birds) feces which are a source of pathogenic bacteria, viruses, protozoa and helminths (WHO, 2008). Among pathogenic microorganisms present in water, E. coli is the most common indicator for faecal contamination in drinking water (Ashbolt, 2015). Chemical disinfection is effective against many pathogens (especially bacteria). But the use of physical barriers such as membranes to remove pathogens is particularly interesting since it is efficient and lowers the chemical demand EPA, 2012). Membrane limitations lie nevertheless on damages that can occur during water treatment and thus alter their retention performances. Compared to polymeric membranes, inorganic porous membranes are more robust. They are commonly used to filter colloidal suspensions, to remove natural organic matter and pathogenic microorganisms contained in surface waters (Burggraaf and Cot, 1996).

Ceramic membranes are a class of inorganic materials which have specific properties such as chemical stability, thermal and mechanical resistance, wide diversity of microstructures, porosities and accessible geometries (Burggraaf, 1996). They are prepared by deposition of one or several active layer of desired materials $\left(\mathrm{TiO}_{2}, \mathrm{ZrO}_{2}, \mathrm{ZnAl}_{2} \mathrm{O}_{4}\right.$, zeolite, etc.) on an inorganic membrane support which could be elaborated with mineral clays (Saffaj et al., 2004; Achiou et al., 2018). Nowadays, various membrane supports have been elaborated for microfiltration and ultrafiltration 
using different local mineral clays from Moroccan (Saffaj et al., 2006; Saja et al., 2018; Majouli et al., 2011), Tunisia (Masmoudi et al., 2007; Khemakhem et al., 2009), China (Kumar et al., 2019), Algeria (Bouzerara et al., 2006) with specific properties (porosity and pores diameter). These works have used Methocel ${ }^{\mathrm{TM}}$ as a plasticizer agent, gelatin as a gelling agent as well as amijel, amidon and calcium carbonate as pore-forming agents. The porosity can also be generated by using porogens arisen from natural wastes, which makes the membrane conception environmentally friendly (Burggraaf and Cot, 1996). That is the case of ashes obtained from animal bones, rice husk wastes (Hubadillah et al., 2018) and sugarcane bagasse (Jamalludin et al., 2018) or banana peel powders (Mouiya et al., 2019) that are added to the mineral clays to create porosity and then make membrane supports used for microfiltration and ultrafiltration purposes.

In the specific context of Cameroon, the most abundant wastes available to generate porogens for membrane elaboration from local clays are coconut husks and eggshells. The eggshells contain about $94 \%$ of calcium carbonate and are similar to the ceramic formed at low temperature (Nys et al., 2010). The addition of calcium carbonate in clay also contributes to increasing its mechanical strength (Suresh and Pugazhenthi, 2016). In the same way, coconut husks were used to activate charcoal which results in a good porosity (mixture of meso and micropores) and specific surface areas between $500 \mathrm{~m}^{2} / \mathrm{g}$ and $1300 \mathrm{~m}^{2} / \mathrm{g}$ (Bamba et al., 2009). Considering these specific properties, coconut husks and eggshells could be good candidates as additives to create pores and to ensure a good mechanical resistance of the composite material. This all the more relevant that these natural wastes accumulate in nature which can induce environmental concerns. To the best of our knowledge, 
none membrane support elaborated from a mixture of clays, coconut husks and eggshells was reported yet.

The aim of this work was consequently to elaborate and characterize ceramic membrane supports based on kaolinite clays from Cameroon, coconut husks and egg shells. The obtained membrane supports were fully characterized using scanning electron microscopy (SEM), Energy-dispersive X-ray spectroscopy (EDX), thermogravimetric analysis (TGA)/Differential Scanning Calorimetry (DSC), X-ray diffraction $(\mathrm{XRD})$ and mercury porosimetry. A non-pathogenic strain of $E$. coli was chosen in this study as a model for bacterial contamination since its exhibit similar morphology and biochemical structure than pathogenic E. coli strains (Ahmetagic and Pemberton, 2011). The ability of the membrane support to retain E. coli bacteria from water was finally assessed.

\section{Materials and methods}

\subsection{Raw materials}

Two kaolinite clays were used for this work. These clays were sampled in WestCameroon at a depth of $1.8 \mathrm{~m}$ using hand augers. The first clay was collected in Mayouom and the second one in Koutaba. Coconut husks were collected nearby a coconut market in Edea (Littoral-Cameroon) and eggshells were collected in several cafeterias in Yaounde (Centre-Cameroon).

\subsection{Elaboration of porous ceramic supports}

Coconut husks and eggshells were firstly washed several times with distilled water. They were then dried with mineral clays in an oven (VT5042 EK, Heraeus) at 
$100^{\circ} \mathrm{C}$ for 48 hours. Each sample was thereafter powdered in a porcelain mortar until full passage through $100 \mu \mathrm{m}$ mesh opening sieve.

25 plastic formulations with variable percentages of Mayouom clay (35-75\% $w / w)$, coconut husks $(0-25 \% w / w)$ and eggshells $(0-25 \% w / w)$ were tested; each formulation contained $25 \%$ of Koutaba clay and $15 \%$ of deionized water (i.e. $15 \mathrm{~mL}$ of deionized water for $100 \mathrm{~g}$ of plastic powder).

Ceramic membrane supports were elaborated according to the following sequence: (i) preparation of a plastic powder with different percentages of raw materials; (ii) shaping the plastic powder (physical mixture) by a hydraulic press (FED S. CARVER INC Menomonee Falls Wisconsin 53051) at 3.5 tons to obtain ceramic disks of $4 \mathrm{~cm}$ diameter and $2 \mathrm{~mm}$ thickness; (iii) drying the supports obtained for $48 \mathrm{~h}$ at room temperature to reach maturity and (iv) consolidation of the dried supports by thermal treatment at different temperatures: $800^{\circ} \mathrm{C}, 900^{\circ} \mathrm{C}$ or $1000^{\circ} \mathrm{C}$. The implemented temperature program consisted in heating the supports from room temperature to $500^{\circ} \mathrm{C}$ with a heating speed of $1^{\circ} \mathrm{C} \mathrm{min}^{-1}$, and then increasing to the final temperature desired with a heating speed of $2^{\circ} \mathrm{C} \mathrm{min}^{-1}$. Finally, supports were cooled until room temperature with a $5^{\circ} \mathrm{C} \mathrm{min}^{-1}$ cooling speed.

\subsection{Materials characterizations}

Different techniques were used to characterize raw materials and the elaborated supports. X-ray diffraction (XRD) measurements were carried out on raw powders with a Bruker D5000 X-ray powder diffractometer employing Cu-Ka radiation of the wavelength of $1.5406 \AA$ at room temperature at $40 \mathrm{kV}$ and $30 \mathrm{~mA}$ in a $2 \theta$ range from 2 to $80^{\circ}$ with scanning rate of $0.5 / \mathrm{min}$ and step of $0.02^{\circ}$. Energy Dispersive X-ray (EDX) analysis on powder using Zeiss EVO HD15 allowed to 
125 determine the chemical composition. A Fourier transform infrared spectrophotometer

126 (FTIR) Nexus was used to identify the chemical function groups of clays.

127 Thermogravimetric analysis (TGA) and Differential Scanning Calorimetry (DSC) were

128 carried out under air with a temperature rise of $5^{\circ} \mathrm{C} \cdot \mathrm{min}^{-1}$ up to $1000^{\circ} \mathrm{C} . \alpha-\mathrm{Al}_{2} \mathrm{O}_{3}$ was

129 used as a reference. Scanning electron microscopy (SEM) using a Hitachi S4800

130 was used to check the presence of possible defects in the prepared membrane 131 supports. XRD, EDX, FITR, TGA/DSC and SEM analyses were carried out once. The 132 porosity and the mean pore diameter were determined using a mercury porosimeter 133 (Auto Pore IV 9500 Micromeritics). Porosimetry analyses were done once, except for 134 the finally selected support whose measures were reproduced.

With the aim to use these membrane supports for water filtration, their resistance to water and their water absorption were determined. To do so, the supports were boiled in distilled water for $4 \mathrm{~h}$ and then let at room temperature for 24 $\mathrm{h}$ in distilled water. Water absorption (WA) was calculated according to Eq. (1).

$$
\mathrm{WA}=\frac{\left(M_{f}-M_{i}\right)}{M_{f}} \times 100 \quad \text { Eq. (1) }
$$

where $M_{i}$ is the initial mass of the support and $M_{f}$ the mass after the treatment of the 141 membrane supports in water. WA measurements were reproduced (2 samples per 142 support tested).

The mechanical resistance of the supports was also assessed and measured by the three points mechanical test (LLOYD Instrument) applied to sintered parallelepiped test bars. The distance $(L)$ separating the two extremities of the test bar was $40 \mathrm{~mm}$. Compressive strength $(\sigma)$ was calculated using Eq. (2).

$$
\sigma=\frac{3 \mathrm{PL}}{2 \mathrm{bh}^{2}}
$$


where: $\sigma$ is the compressive strength (MPa), $\mathrm{P}$ the total charge applied to the flexural

149 fracture $(N), L$ the distance between the two extremities of the test bar $(L=40 \mathrm{~mm}), b$ 150 the material width $(b=40 \mathrm{~mm})$ and $\mathrm{h}$ the material thickness $(\mathrm{h}=9 \mathrm{~mm})$. For each support tested, compressive strengths were measured twice (2 samples per support).

\subsection{Permeability of the membrane support}

Permeability is the ability of the membrane support to be crossed by a liquid under pressure. A filtration system for flat sheet membranes was used for the flow measurements that were performed in a dead-end mode and at a constant transmembrane pressure $(\Delta \mathrm{P})$. The elaborated membrane support was used as a membrane and three $\Delta P$ were implemented: $0.1,0.2$ and 0.3 bar. A filtration cell (Millipore, France, Model 8050) without stirring and with a membrane surface $S$ of about $12.5 \mathrm{~cm}^{2}$ was employed. Fig. 1 illustrates the membrane system.

Fig. 1. Filtration system

This filtration cell was connected to a feed tank $(1 \mathrm{~L})$ containing either deionized water or Phosphate-Buffered Saline (PBS) at $12.9 \mathrm{mM}, \mathrm{pH}=7.0 \pm 0.1$ to allow longer filtration times. PBS is a water-based salt solution made of $\mathrm{KH}_{2} \mathrm{PO}_{4} 1.06 \mathrm{~g} / \mathrm{L}$ and $\mathrm{Na}_{2} \mathrm{HPO}_{4} .12 \mathrm{H}_{2} \mathrm{O} 4.34 \mathrm{~g} / \mathrm{L}$.

For each $\Delta \mathrm{P}$, the permeate flow was monitored over time (every $5 \mathrm{~s}$ ) with an electronic balance until to reach a constant value. For the support finally selected, the permeate flow was measured twice independently; the data were then smoothed and averaged. The stabilized permeate flows were then normalized by the membrane surface to get the corresponding flow densities $\left(\mathrm{J}, \mathrm{L} / \mathrm{h} / \mathrm{m}^{2}\right)$. Flow densities were finally 
173 reported against $\Delta P$ to obtain the mean support permeability $\left(L_{p}, L / h / m^{2} /\right.$ bar $)$

174 according to Darcy's law (Eq. (3)).

\subsection{Assessment of the bacterial retention}

\subsubsection{Preparation of the bacterial suspension}

A non-pathogenic Gram-negative Escherichia coli bacterium (K12 DSM 423, from DSMZ, Germany) was used for the retention tests. A ready-to-use Lysogeny Broth (LB) Miller culture medium was used for growth and counting (Sigma, France). The bacterial cultures were prepared from frozen aliquots of $E$. coli stored at $-20^{\circ} \mathrm{C}$. The aliquots were inoculated into fresh LB medium (4\% v/v) and incubated for $18 \mathrm{~h}$ at $30^{\circ} \mathrm{C}$ under constant stirring (180 rpm), until the optical density at $600 \mathrm{~nm}\left(\mathrm{OD}_{600 \mathrm{~nm})}\right.$ of the bacterial culture reached nearly 5 (which corresponds approximately to $10^{9}$ $\mathrm{CFU} / \mathrm{mL}$ ). In these conditions, bacteria were in a stationary phase. Once prepared, the bacterial culture was diluted by decades in PBS $(12.9 \mathrm{mM}, \mathrm{pH}=7.0 \pm 0.1)$ prepared in deionized water and exempt of nutriments to reach a bacterial concentration of about $10^{2} \mathrm{CFU} / \mathrm{mL}$. PBS allows maintaining the bacteria cells in life while avoiding their growth.

\subsubsection{Bacterial counting}

The bacterial concentrations in liquid samples were measured by the conventional plaque assay method. For that, liquid samples (400 $\mu \mathrm{L}$ each) were spread onto LB agar plates obtained by adding $15 \mathrm{~g} / \mathrm{L}$ of microbiological agar

196 (Sigma, France) into LB solution. All plates were then incubated for $48 \mathrm{~h}$ at $37^{\circ} \mathrm{C}$.

197 Once the cultivable bacteria had grown on plates, the colonies were counted, 
knowing that each colony stemmed from one initial bacterium. The concentrations of bacteria in the samples were calculated as the average number of the colonies divided by the volume inoculated (i.e., $400 \mu \mathrm{L}$ ). Each counting was duplicated. The quantification limit was $3 \mathrm{CFU} / \mathrm{mL}$. Negative controls (i.e., without bacteria) were always run in parallel to check the sterility.

\subsubsection{Filtration of the bacterial suspension}

Filtration was carried out in the filtration cell presented in Fig. 1. Before bacteria filtration, the whole filtration system without membrane was disinfected with ethanol (70\% in water) and then massively washed with sterile ultrapure water. A bacterial suspension at about $10^{2} \mathrm{CFU} / \mathrm{mL}$, prepared according to section 2.5.1, was used as the feed. The bacterial concentration of the suspension was initially enumerated (section 2.5.2). Filtration was performed with a transmembrane pressure $\Delta \mathrm{P}$ fixed to 0.2 bar and the permeate flow $(\mathrm{Q}, \mathrm{L} / \mathrm{h})$ was monitored over time with an electronic balance. At the end of the filtration, the bacteria concentration was measured in the permeate (Fig. 1) by the plaque assay method (section 2.5.2). The bacterial retention of the support that was finally selected was assayed twice.

\section{Results and discussion}

\subsection{Raw materials characterizations}

Two natural clays were used in this study. Their crystalline phase was investigated by X-ray diffraction. Fig. 2 presents the XRD patterns of Mayouom and Koutaba clays, either non-sintered or sintered at $900^{\circ} \mathrm{C}$. 
222 Fig. 2. XRD patterns of Mayouom (a) and Koutaba (b) clays, either non-sintered 223 (dark curves) or sintered at $900^{\circ} \mathrm{C}$ (red curves).

According to the International Centre for Diffraction Data (ICDD), non-sintered

Mayouom (Fig. 2a) and Koutaba (Fig. 2b) clays exhibit the peaks corresponding to kaolinite (ICDD 01-083-0971), illite (ICDD 00-015-0603), quartz a (ICDD 00-0050490) and anatase (ICDD 01-071-1167). Goethite (ICDD 01-073-6522) appears only for Koutaba clay (Fig. 2b).

After sintering at $900{ }^{\circ} \mathrm{C}$, kaolinite and illite disappear to give mullite (ICDD-98-028246), quartz a gives quartz $\beta$ (ICDD-00-005-0490) and anatase gives rutile (ICDD01-076-0324) in both cases.

Chemical analyses of clays, coconut husks and eggshells were carried out by EDX analysis (Fig. S1). The major phase in Mayouom clay and Koutaba clay contains aluminum and silicon suggesting the presence of kaolinite. The presence of silicon can be also attributed to quartz evidenced by DRX (Fig. 2). Coconut husks are constituted exclusively of carbon and oxygen, reflecting organic matter. Eggshells contain exclusively carbon, oxygen and calcium that can be attributed to calcium carbonates. $900^{\circ} \mathrm{C}$ are presented in Fig. 3.

Fig. 3. FTIR spectra of Mayouom clay (a) and Koutaba clay (b), either non-sintered (dark curves) or sintered at $900^{\circ} \mathrm{C}$ (red curves). 
The FTIR spectra of raw Mayouom clay presented in Fig. 3a show absorption bands located at $3693 \mathrm{~cm}^{-1}$ and $3620 \mathrm{~cm}^{-1}$ that can be attributed to the $\mathrm{O}-\mathrm{H}$ bond vibration of hydroxyl groups (El Qacimi et al., 2019).

According to Masmoudi et al. (2007) and Majouli et al. (2011), the bands located at $1003 \mathrm{~cm}^{-1}$ and $1088 \mathrm{~cm}^{-1}$ are attributed to symmetrical and asymmetrical elongation vibrations of the Si-O-Si bond; the vibration band observed at $910 \mathrm{~cm}^{-1}$ corresponds to the deformation of the $\mathrm{Al}-\mathrm{OH}$ bond while the other one observed at $750 \mathrm{~cm}^{-1}$ corresponds to the different modes of Si-O-Al bond (where Al is tetracoordinate).

The presence of $\mathrm{O}-\mathrm{H}$ groups, $\mathrm{Si}-\mathrm{O}-\mathrm{Si}, \mathrm{Al}-\mathrm{OH}$ and $\mathrm{Si}-\mathrm{O}-\mathrm{Al}$ bonds can be referred to the presence of kaolinite and illite shown by XRD patterns of Mayouom clay (Fig. 2a).The bands located at $675 \mathrm{~cm}^{-1}$ are attributed to Ti-O (El Qacimi et al., 2019) which can be correlated to the presence of anatase.

After sintering Mayouom clay at $900^{\circ} \mathrm{C}$ (Fig. 3a), only two bands appear at $1055 \mathrm{~cm}^{-1}$ and $773 \mathrm{~cm}^{-1}$ corresponding to $\mathrm{Si}-\mathrm{O}-\mathrm{Si}$ and $\mathrm{Si}-\mathrm{O}-\mathrm{Al}$ bonds respectively. These groups can be attributed to the presence of mullite shown by XRD patterns of sintered clays.

The FTIR spectra of raw Koutaba clay presented in Fig. 3b exhibit similar absorption bands as raw Mayouom clay. The bands located at $3690 \mathrm{~cm}^{-1}$ and 3620 $\mathrm{cm}^{-1}$ can be attributed to the $\mathrm{O}-\mathrm{H}$ bond vibration of hydroxyl groups while the bands located at $1010 \mathrm{~cm}^{-1}$ are attributed to Si-O-Si bond. The vibration band observed at $910 \mathrm{~cm}^{-1}$ corresponds to $\mathrm{Al}-\mathrm{OH}$ bond and the bands observed at $777 \mathrm{~cm}^{-1}$ correspond to Si-O-Al bond. The other ones located at $677 \mathrm{~cm}^{-1}$ can be attributed to Fe-O and Ti-O bond. The presence of $\mathrm{O}-\mathrm{H}$ groups, Si-O-Si, Al-OH, Si-O-Al, Ti-O and Fe-O bonds can be correlated to the presence of kaolinite, illite and goethite seen by 
appear at $1051 \mathrm{~cm}^{-1}$ and $779 \mathrm{~cm}^{-1}$ corresponding to Si-O-Si and Si-O-Al bonds respectively, which can be linked to the presence of mullite shown by XRD (Fig. 2b).

TGA and DSC curves obtained for the raw materials are shown in Fig. 4.

Fig. 4. TGA/DSC curves for Mayouom clay (a), Koutaba clay (b), coconut husks (c) and eggshells (d).

Mayouom clay curves (Fig. 4a) show an exothermic peak at $260^{\circ} \mathrm{C}$ with a mass loss of $2 \%$ which corresponds to the organic matter decomposition (Khemakhem et al., 2009). At $500^{\circ} \mathrm{C}$, an endothermic peak is observed with a mass loss of $9 \%$ corresponding to the deshydroxylation of kaolinite into metakaolinite (Saffaj et al., 2006; El Qacimi et al., 2019).

Koutaba clay curves (Fig. 4b) show an endothermic peak at $70^{\circ} \mathrm{C}$ with a mass loss of $2 \%$ which corresponds to the elimination of the free water on the material surface (Masmoudi et al., 2007; Majouli et al., 2011; El Qacimi et al., 2019). An exothermic peak is observed at $260^{\circ} \mathrm{C}$ with a mass loss of $3 \%$ corresponding to the organic matter decomposition (Khemakhem et al., 2009). At $460^{\circ} \mathrm{C}$, an endothermic peak is observed with a mass loss of $11 \%$ corresponding to the dehydroxylation of kaolinite into metakaolinite. At $930^{\circ} \mathrm{C}$, an exothermic peak is observed, without any mass loss, corresponding to the structural reorganization of metakaolinite into spinel phase (primary mullite) (Majouli et al., 2011;El Qacimi et al., 2019).

The coconut husks curve (Fig. 4c) shows an endothermic peak at $40^{\circ} \mathrm{C}$ with a mass loss of $4 \%$ which corresponds to the elimination of the free water. At $320^{\circ} \mathrm{C}$, an exothermic peak is observed with a mass loss of $50 \%$ corresponding to the pyrolysis 
of hemicellulose. Another exothermic peak is observed at $440^{\circ} \mathrm{C}$ with a mass loss of $46 \%$ corresponding to the pyrolysis of cellulose (Liyanage and Pieris, 2015).

Eggshells curves (Fig. 4d) show an exothermic peak at $340^{\circ} \mathrm{C}$ with a mass loss of $6 \%$ corresponding to the organic matter decomposition (Khemakhem et al., 2009). At $720^{\circ} \mathrm{C}$, an endothermic peak with a mass loss of $42 \%$ is observed corresponding to the decomposition of calcium carbonate into calcium oxide (Périnet, 1962). In fact, the TGA/DSC curves of pure calcium carbonate exhibited an endothermic peak at higher temperatures, i.e., between $900^{\circ} \mathrm{C}$ and $1000^{\circ} \mathrm{C}$ (Klosek-Wawrzyn et al., 2013). This temperature difference could be explained by the presence of organic matter residue on eggshells which act as an impurity.

\subsection{Elaboration and choice of the porous supports}

All supports were elaborated by the method described in section 2.2. After sintering at $800^{\circ} \mathrm{C}, 900^{\circ} \mathrm{C}$ and $1000^{\circ} \mathrm{C}$, all supports exhibit similar physical aspects for a same sintering temperature (Fig. 5)

Fig. 5. General physical aspects of supports after sintering at $800^{\circ} \mathrm{C}, 900^{\circ} \mathrm{C}$ and $1000^{\circ} \mathrm{C}$.

At $800^{\circ} \mathrm{C}$ and $1000^{\circ} \mathrm{C}$, almost all supports were crumbled due to the non-grain cohesion within the material. But at $900^{\circ} \mathrm{C}$, all formulations exhibited a good physical aspect. Supports sintered at $900^{\circ} \mathrm{C}$ were thus considered for the rest of the study. In order to have supports with good water permeability, 5 membrane supports sintered at $900^{\circ} \mathrm{C}$ were chosen among the 25 supports elaborated on the basis of their porosity (Table 1). The 5 selected supports, marked in bold in Table 1, have 
porosities higher than $50 \%$. The formulation composition and particularly the porogens content appear thus to be a key element regarding material porosity.

Table 1. Porosities and average pore size diameters of the elaborated membrane supports.

Water absorption ability and mechanical properties of the 5 selected supports sintered at $900^{\circ} \mathrm{C}$ were assessed. To do so, the supports were boiled in distilled water during $4 \mathrm{~h}$ and then let at room temperature for $24 \mathrm{~h}$ in the same distilled water. S1520, S2015 and S2020 crumbled while S1510 and S2010 kept their integrity even after $48 \mathrm{~h}$ in distilled water. The water absorption (WA) of these both supports were measured. It appears that WA is higher for S2010 (31.1 $\pm 0.2 \%)$ than for S1510 $(26.1 \pm 0.3 \%)$. It is worth noticing that the same values are reached after only immersing $4 \mathrm{~h}$ the supports in distilled water at room temperature.

Mechanical tests were then performed on S1510 and S2010. The compressive strength of support S1510 is twice as much as S2010 (2.04 \pm 0.06 Mpa vs. $1.30 \pm$ $0.03 \mathrm{Mpa}$ ). This induced that support S2010 broke when it was set up inside the filtration cell making water flow measurements impossible with this support. For this reason, the membrane support $\mathbf{S} 1510$ was selected as the most suitable for water filtration applications.

\subsection{Characterizations of the selected support $\mathrm{S} 1510$}

Fig. 6 shows the XRD patterns of the membrane support $S 1510$ sintered at $900^{\circ} \mathrm{C}$ and the TGA/DSC curves of the support before sintering. 
Fig. 6. XRD patterns of the membrane support $\mathrm{S} 1510$ sintered at $900^{\circ} \mathrm{C}$ (a) and TGA/DSC curves of the support before sintering (b).

According to the International Centre for Diffraction Data (ICDD) and Fig. 6a, peaks corresponding to quartz $\beta$ (ICDD 00-005-0490), mullite (ICDD 98-02-8246), anorthite (ICDD 00-041-1486) and rutile ICDD 00-015-0603) are identified. The

352 formation of mullite at low temperature $\left(900^{\circ} \mathrm{C}\right)$ is due to the presence of anorthite. In fact, the heating of kaolinite (main phase of raw clays used) gives metakaolinite (Fig. 4a and 4b) which in presence of calcium oxide (Fig. 4d) gives anorthite. Then, the heating of the overage of metakaolinite mixed to anorthite for a longer time at $900^{\circ} \mathrm{C}$ promotes the formation of mullite (Traoré et al., 2003; Klosek-Wawrzyn et al., 2013).

Chemical analyses of selected membrane support $\mathrm{S} 1510$ were carried out by EDX analysis (Fig. S1). The major phase contains aluminum, silicon and calcium suggesting the presence of anorthite evidenced by XRD. The presence of aluminum and silicon can be also attributed to mullite and to quartz.

TGA and DSC curves of the raw plastic powder formulation used to make the membrane support are shown in Fig. 6 b. At $50^{\circ} \mathrm{C}$, an endothermic peak is observed with a mass loss of $7 \%$ which corresponds to the elimination of free water on the material surface (Masmoudi et al., 2007;Majouli et al., 2011). At $340^{\circ} \mathrm{C}$, an exothermic peak is observed with a mass loss of $15 \%$ which corresponds to the decomposition of organic matter from eggshells and coconut husks (cellulose and hemicellulose) (Liyanage and Pieris, 2015). At $500^{\circ} \mathrm{C}$, an endothermic peak is 368 observed with mass losses of $6 \%$ corresponding to the dehydroxylation of kaolinite 369 into metakaolinite (Saffaj et al., 2006;El Qacimi et al., 2019). At $700^{\circ} \mathrm{C}$, an 
endothermic peak is observed with a mass loss of $4 \%$ which corresponds to the transformation of metakaolinite mixed to calcium oxide ( due to the decomposition of eggshells) into anorthite (Périnet, 1962; Traoré et al., 2003).

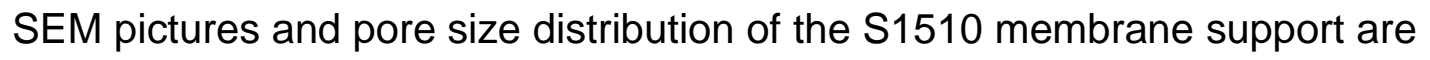
presented in Fig. 7.

375

Fig. 8. Flow density and permeability curves obtained with deionized water (a, c) and

Fig. 7. SEM pictures at different magnifications $(a, b, c, d)$ and pore size distribution (e) of the support SN1510.

Both top and cross views of the membrane support $\mathrm{S} 1510$ show that the grains are interconnected each other forming a compact structure (Fig. $7 a$ to $\mathbf{d}$ ). The pore size distribution within the support was investigated by mercury porosimetry for filtration purpose (Fig. 7e). The distribution shows that the membrane support contains a mixture of macropores and mesopores with mean diameters of $2.32 \mu \mathrm{m}$ and $0.03 \mu \mathrm{m}$ respectively which makes the support eligible for microfiltration.

\subsection{Permeability of the selected support SN1510}

Fig. 8 shows the flow densities measured over time with deionized water (Fig. 8a) and PBS (Fig. 8b) for different transmembrane pressures $(\Delta P)$, and the corresponding permeability curves obtained with deionized water (Fig. 8c) and PBS (Fig. 8d) for the selected support S1510. PBS (b, d) respectively. 
395 Prior to permeability tests, the support was conditioned by immersion in deionized 396 water for $4 \mathrm{~h}$ at room temperature to saturate the pores of the support with water. 397 Then, the flow densities were measured for different pressures $(0.1 ; 0.2$ and 0.3 bar). 398 Whatever the matrix (either deionized water or PBS), the flow density stabilized quickly, i.e., after 2 min for each pressure. As expected, experiments showed that the

400

401

402

403

404

405

406

407

408

409

410 flow density through the support increased proportionally with the pressure (Fig. 8a and $\mathbf{8 b}$ ). Increasing the pressure increases indeed the convective driving force across the membrane support (Mohamed Bazin et al., 2019). In addition, the permeability tests showed that the flow densities obtained with deionized water (Fig. 8a) were significantly higher than the ones obtained with PBS (Fig. 8b). In fact, the presence of salts in PBS may induce a concentration polarization near the membrane support, i.e., a salt concentration gradient at the membrane/solution interface (laich and Messaoudi, 2014). This concentration gradient of salts formed on the membrane support becomes an additional resistance to the mass transfer that reduces the flow density. As a consequence, the mean support permeability for PBS (7259 \pm 774 $\mathrm{L} / \mathrm{h} / \mathrm{m}^{2} /$ bar, Fig. 8d) is lower than the one measured for deionized water (14013 \pm $1251 \mathrm{~L} / \mathrm{h} / \mathrm{m}^{2} /$ bar, Fig. 8c). It is worth highlighting that the water permeability reached with the elaborated support $\mathrm{S} 1510$ is higher than the water permeability reported in other works for microfiltration ceramic membranes elaborated by natural mineral clays (Table 3). $867 \mathrm{~L} / \mathrm{h} / \mathrm{m}^{2} /$ bar, Khemakhem et al., 2009; $1434 \mathrm{~L} / \mathrm{h} / \mathrm{m}^{2} /$ bar, Saja et al., 2018; $121 \mathrm{~L} / \mathrm{h} / \mathrm{m}^{2}$ Abar, El Qacimi et al., 2019).

Table 3. Comparison with other works reported in literature. 


\subsection{Bacterial retention of the selected support $\mathrm{S} 1510$}

In order to assess the ability of the selected support to retain bacteria, a bacterial suspension at about $10^{2} \mathrm{CFU} / \mathrm{mL}$ in PBS was filtrated at 0.2 bar in a deadend filtration cell (Fig. 1). PBS was chosen as a matrix to avoid osmosis phenomena that could lyse bacteria cells; besides, this matrix is more representative of real water in terms of ionic force. Bacteria were counted in the feed suspension and the permeate (Fig. 1) by the plaque assay method (section 2.5.2). Table 2 shows the results obtained.

Table 2. Counted bacteria in the feed and permeate.

The concentration of bacteria in the permeate was reduced by a factor 10 compared to the feed (Table 2): 32 vs $307 \mathrm{CFU} / \mathrm{mL}$ corresponding to $8 \times 10^{3}$ vs. $8 \times$ $10^{4} \mathrm{CFU}$ since $250 \mathrm{~mL}$ of bacterial suspension were filtrated. This means that the selected ceramic support S1510 retains about $90 \%$ of bacteria, corresponding to 1 log-removal. The selected support allows thus a significant bacterial retention (WHO, 2008) that is consistent with the bacterial retention reported by Kaetzl et al. (2020) for Miscanthus-biochar filters (Table 3). Knowing that the usual E. coli bacteria size is about $0.6-4 \mu \mathrm{m}$ (Sayato, 1989), retention can be explained by steric considerations since the support pores range from $0.03 \mu \mathrm{m}$ to $2.32 \mu \mathrm{m}$ and even up to $0.01 \mu \mathrm{m}$ (Fig. 7e). The pore size distribution also explains the presence of bacteria in the permeate since the bacteria meeting the biggest pores can pass through the support.

In addition, it is worth noticing that the permeate flow density at 0.2 bar did not exhibit any decrease during the filtration of the bacterial feed (Fig. 9). Besides, the flow densities obtained with PBS alone $\left(1384 \mathrm{~L} / \mathrm{h} / \mathrm{m}^{2}\right)$ and with the bacterial feed prepared 
444 in PBS $\left(1198 \mathrm{~L} / \mathrm{h} / \mathrm{m}^{2}\right)$ did not show significant difference. This means that little or no

445 fouling occurred during the filtration. Longer filtration time will be further implemented 446 to study the fouling.

Fig. 9. Permeate flow densities at 0.2 bar with PBS and bacterial feed.

\section{Conclusions}

451

452

453

454

455

456

457

458

459

460

461

462

463

A new ceramic membrane support was elaborated in this work from natural sources including low-cost organic wastes. The formulation composition and the sintering temperature were evidenced to impact the material porosity and mechanical resistance. It was prepared from a plastic powder containing $75 \%$ of natural Cameroonian clays, $15 \%$ of coconut husks and $10 \%$ of eggshells. The elaboration protocol was quite simple since the powder was shaped (disk sheet) by pressing and then sintering at $900^{\circ} \mathrm{C}$. The structural properties of the ceramic support elaborated are satisfying for microfiltration use in terms of porosity (52\%) and pore distribution (with a mean pore diameter of $0.08 \mu \mathrm{m}$ ). Its water and PBS permeabilities are respectively $14013 \mathrm{~L} / \mathrm{h} / \mathrm{m}^{2} /$ bar and $7258 \mathrm{~L} / \mathrm{h} / \mathrm{m}^{2} /$ bar. Compared to other studies in which local natural clays have been used with or without organic wastes to make ceramic membranes, the resulting porosity and permeability were among the highest ones reported, which could make possible an application at a larger scale. In addition, this membrane support has the ability to retain $90 \%$ of $E$. coli bacteria and can be considered for a preliminary water treatment. Work is in progress in order to deposit an additional ceramic membrane layer to improve the bacteria retention. Membrane fouling will also be further investigated. As a perspective, a multi-tubular 
geometry of the support could be envisaged for the scale-up and to work in a parallel flow mode to contribute to reduce the fouling during operation.

\section{Acknowledgements}

The French Embassy in Cameroon is thanked for supporting this work at the European Institute of Membranes in Montpellier-France.

\section{References}

Achiou, B., Beqqour, D., Elomari, H., Bouazizi, A., Ouammou, M., Bouhria, M., Aaddane, A., Khiat, K., \& Alami Younssi, S. (2018). Preparation of inexpensive $\mathrm{NaA}$ zeolite membrane on pozzolan support at low temperature for dehydration of alcohol solutions. Journal of Environmental Chemical Engineering, 6(4), 4429-4437. https://doi.org/10.1016/j.jece.2018.06.049

Ahmetagic, A., \& Pemberton, J. M. (2011). Antibiotic resistant mutants of Escherichia coli K12 show increases in heterologous gene expression. Plasmid, 65(1), 5157. https://doi.org/10.1016/j.plasmid.2010.11.004

Ashbolt, N. J. (2015). Microbial Contamination of Drinking Water and Human Health from Community Water Systems. Current Environmental Health Reports, 2(1), 95-106. https://doi.org/10.1007/s40572-014-0037-5

Bamba, D., Dongui, B., Trokourey, A., \& Zoro, G. E. (2009). Etudes comparées des méthodes de préparation du charbon actif , suivies d ' un test de dépollution d ' une eau contaminée au diuron Comparative studies of activated carbon preparation methods, followed by depollution test of diuron contaminated water. 

J. Soc. Ouest-Afr. Chim (2009) 028, 028(October 2015), 41-52.

492

493

494

495

496

497

498

499

500

501

502

503

504

505

506

507

508

509

510

511

512

513

514

Bouzerara, F., Harabi, A., Achour, S., \& Larbot, A. (2006). Porous ceramic supports for membranes prepared from kaolin and doloma mixtures. Journal of the European Ceramic Society, 26(9), 1663-1671. https://doi.org/10.1016/j.jeurceramsoc.2005.03.244

Burggraaf, A. J. (1996). Chapter 2 Important characteristics of inorganic membranes. Membrane Science and Technology, 4(C), 21-34. https://doi.org/10.1016/S0927-5193(96)80005-2

Burggraaf, A. J., \& Cot, L. (1996). Chapter 1 General overview, trends and prospects. Membrane Science and Technology, 4(C), 1-20. https://doi.org/10.1016/S09275193(96)80004-0

El Qacimi, N., El Baraka, N., Saffaj, N., Mamouni, R., Laknifli, A., Alami Younssi, S., Faouzi, A., \& Zidouh, H. (2019). Preparation and characterization of flat membrane support based on Sahara Moroccan clay: Application to the filtration of textile effluents. Desalination and Water Treatment, 143, 111-117. https://doi.org/10.5004/dwt.2019.23516

EPA (2012). "Edition of the Drinking Water Standards and Health Advisories." Office of Water, United 580 States Environmental Protection Agency 822-S-12-001.

Hubadillah, S. K., Othman, M. H. D., Ismail, A. F., Rahman, M. A., Jaafar, J., Iwamoto, Y., Honda, S., Dzahir, M. I. H. M., \& Yusop, M. Z. M. (2018). Fabrication of low cost, green silica based ceramic hollow fibre membrane prepared from waste rice husk for water filtration application. Ceramics International, 44(9), 10498-10509. 
Laich, S., and Messaoudi, L. (2014). Preparation of new ceramic supports macroporous for microfiltration and ultrafiltration membranes based Moroccan clay. IOSR Journal of Mechanical and Civil Engineering, 11(2), 56-62. https://doi.org/10.9790/1684-11265662

Jamalludin, M. R., Harun, Z., Othman, M. H. D., Hubadillah, S. K., Yunos, M. Z., \& Ismail, A. F. (2018). Morphology and property study of green ceramic hollow fiber membrane derived from waste sugarcane bagasse ash (WSBA). Ceramics International, 44(15), 18450-18461. https://doi.org/10.1016/j.ceramint.2018.07.063

Kaetzl, K., Lübken, M., Nettmann, E., Krimmler, S., \& Wichern, M. (2020). Slow sand filtration of raw wastewater using biochar as an alternative filtration media. Scientific reports, 10(1), 1-11.

Khemakhem, S., Larbot, A., \& Ben Amar, R. (2009). New ceramic microfiltration membranes from Tunisian natural materials: Application for the cuttlefish effluents treatment. Ceramics International, 35(1), 55-61. https://doi.org/10.1016/j.ceramint.2007.09.117

Klosek-Wawrzyn, E., Malolepszy, J., \& Murzyn, P. (2013). Sintering behavior of kaolin with calcite. Procedia Engineering, 57, 572-582. https://doi.org/10.1016/j.proeng.2013.04.073

Kumar, C. M., Roshni, M., \& Vasanth, D. (2019). Treatment of aqueous bacterial solution using ceramic membrane prepared from cheaper clays: A detailed investigation of fouling and cleaning. Journal of Water Process Engineering, 
Liyanage, C. D., \& Pieris, M. (2015). A Physico-Chemical Analysis of Coconut Shell Powder. Procedia Chemistry, 16, 222-228. https://doi.org/10.1016/j.proche.2015.12.045

Majouli, A., Younssi, S. A., Tahiri, S., Albizane, A., Loukili, H., \& Belhaj, M. (2011). Characterization of flat membrane support elaborated from local Moroccan Perlite. Desalination, 277(1-3), 61-66. https://doi.org/10.1016/j.desal.2011.04.003

Masmoudi, S., Larbot, A., Feki, H. El, \& Amar, R. Ben. (2007). Elaboration and characterisation of apatite based mineral supports for microfiltration and ultrafiltration membranes. Ceramics International, 33(3), 337-344. https://doi.org/10.1016/j.ceramint.2005.10.001

Mohamed Bazin, M., Ahmad, N., \& Nakamura, Y. (2019). Preparation of porous ceramic membranes from Sayong ball clay. Journal of Asian Ceramic Societies, 7(4), 417-425. https://doi.org/10.1080/21870764.2019.1658339

Mouiya, M., Bouazizi, A., Abourriche, A., Benhammou, A., El Hafiane, Y., Ouammou, M., Abouliatim, Y., Younssi, S. A., Smith, A., \& Hannache, H. (2019). Fabrication and characterization of a ceramic membrane from clay and banana peel powder: Application to industrial wastewater treatment. Materials Chemistry and Physics, 227, 291-301. https://doi.org/10.1016/j.matchemphys.2019.02.011

Nys, Y., Hincke, M. T., Hernandez-Hernandez, A., Rodriguez-Navarro, A. B., GomezMorales, J., Jonchère, V., Garcia-Ruiz, J. M., \& Gautron, J. (2010). Structure, propriétés et minéralisation de la coquille de l'œuf Rôle de la matrice organique 

dans le contrôle de sa fabrication. Productions Animales, 23(2), 143-154.

562

Périnet, G. (1962). La synthèse de l'anorthite au cours de la cuisson des céramiques. Bulletin de La Société Française de Minéralogie et de Cristallographie, 85(2), 120-122. https://doi.org/10.3406/bulmi.1962.5555

Saffaj, N., Alami Younssi, S., Albizane, A., Messouadi, A., Bouhria, M., Persin, M., Cretin, M., \& Larbot, A. (2004). Elaboration and properties of TiO2-ZnAl2O4 ultrafiltration membranes deposited on cordierite support. Separation and Purification Technology, 36(2), 107-114. https://doi.org/10.1016/S13835866(03)00203-X

Saffaj, Nabil, Persin, M., Younsi, S. A., Albizane, A., Cretin, M., \& Larbot, A. (2006). Elaboration and characterization of microfiltration and ultrafiltration membranes deposited on raw support prepared from natural Moroccan clay: Application to filtration of solution containing dyes and salts. Applied Clay Science, 31(1-2), 110-119. https://doi.org/10.1016/j.clay.2005.07.002

Saja, S., Bouazizi, A., Achiou, B., Ouammou, M., Albizane, A., Bennazha, J., \& Younssi, S. A. (2018). Elaboration and characterization of low-cost ceramic membrane made from natural Moroccan perlite for treatment of industrial wastewater. Journal of Environmental Chemical Engineering, 6(1), 451-458. https://doi.org/10.1016/j.jece.2017.12.004

Sayato, Y. (1989). WHO Guidelines for Drinking-Water Quality. Eisei Kagaku, 35(5), 307-312. https://doi.org/10.1248/jhs1956.35.307

Suresh, K., \& Pugazhenthi, G. (2016). Development of ceramic membranes from lowcost clays for the separation of oil-water emulsion. Desalination and Water 
585 Traoré, K., Kabré, T. S., \& Blanchart, P. (2003). Gehlenite and anorthite crystallisation from kaolinite and calcite mix. Ceramics International, 29(4), 377383. https://doi.org/10.1016/S0272-8842(02)00148-7

588 WHO, 2008, Guidelines for drinking-water quality: incorporating 1st and 2nd 589 addenda, Recommendations. - -3rd ed. Volume 1, Geneva, World Health Organization.

591 